\title{
FUNCTIONAL ROLE OF FOULING COMMUNITY ON AN ARTIFICIAL REEF AT THE NORTHERN COAST OF RIO DE JANEIRO STATE, BRAZIL*
}

\author{
Werther Krohling**; Daniel Shimada Brotto \& Ilana Rosental Zalmon*** \\ Universidade Estadual do Norte Fluminense - Laboratório de Ciências Ambientais \\ (Av. Alberto Lamego, 2000, 28013-602, Campos dos Goytacazes, RJ, Brasil) \\ **werther_krohling@yahoo.com.bre***ilana@uenf.br
}

\begin{abstract}
A B S T R A C T
The northern coast of Rio de Janeiro State lacks natural consolidate substrates, making it a proper environment to the development of researches using artificial structures. After studies about the type of substrate, concrete seems to be the most appropriate for studying fouling community development. This research was carried out to investigate the functional role of biofouling in the development of the ichthyic community in the north of Rio de Janeiro State. Percentage data of the epibenthic organisms' coverage and samples of the fish community with gillnet and visual census showed that biofouling in artificial reefs might have more than one functional role, acting as a facilitator in the recruitment of fish species and as a link in the trophic marine chain. Through the increase of localized structural complexity provided by the reef itself and by the fouling organisms which act as "engineering species", additional protection options are offered to the ichthyic community, especially recruits. Also, the epibiont biomass represents an important link in the food web, acting either as a direct source or in the transference of energy to higher trophic levels. Through the relationship between the ichthyic and fouling communities we concluded that the functional role of the latter in artificial reef habitats could be characterized mainly as shelter and feeding grounds for few fish species.
\end{abstract}

\section{R E S UMO}

O litoral norte do Estado do Rio de Janeiro possui uma escassez de substrato consolidado natural tornando o ambiente propício para o desenvolvimento de pesquisas com estruturas artificiais. Após estudos conclusivos sobre o tipo de substrato, o concreto parece ser o mais apropriado para o desenvolvimento da comunidade incrustante. Novas pesquisas foram realizadas para investigar o papel funcional da bioincrustação no desenvolvimento da comunidade íctica no norte do Estado do Rio de Janeiro. Dados de porcentagem de cobertura dos organismos epibênticos e amostragens da comunidade nectônica com rede de espera e censo visual, evidenciaram que a bioincrustação em recifes artificiais pode assumir mais de um papel funcional, como facilitadora no recrutamento de espécies de peixes e como elo na cadeia trófica marinha. Através do incremento da complexidade estrutural fornecida pelo próprio recife e pelos organismos incrustantes que atuam como "espécies engenheiras", opções adicionais de proteção são oferecidas para a comunidade íctica, principalmente recrutas. Além disso, a biomassa epibionte representa um importante elo na cadeia alimentar, atuando como fonte direta de alimento e/ou transferência de energia para níveis tróficos superiores. Através da relação entre as comunidades íctica e incrustante, conclui-se que o papel funcional desta última em habitats recifais artificiais caracteriza-se principalmente como abrigo e para algumas espécies também como alimentação.

Descritores: Recife artificial, Bioincrustação, Peixes recifais, Censo visual, Complexidade estrutural, Nível trófico.

Descriptor: Artificial reef, Biofouling, Reef fish, Visual census, Structural complexity, Trophic level.

\section{INTRODUCTION}

The use of artificial habitats to increase fishing activity is a common practice in several

(*) Paper presented at the $2^{\text {nd }}$ Brazilian Congress of Oceanography, on 09-12 October. Vitória, Brazil. countries. Also, artificial reefs are commonly used in underwater leisure activities, as the development of the local marine life provided by the submersed structures makes these environments favorable sites for the practice of recreational diving (Tsumura et al., 1999; Maher 1999; Dowling \& Nichol, 2001).

Different submersed materials commonly used as artificial reef (e.g. concrete, wood, steel, iron) 
show different physical (rugosity) and chemical ( $\mathrm{pH}$, color, hydrophobicity) characteristics. Together with the active behavior of substrate selection by the larvae, different materials will act as selective means for the development of the local fouling community, determining and modifying the colonization and succession patterns (Pearce \& Chang, 1982; Underwood \& Anderson, 1994; Anderson \& Underwood, 1994; Connell \& Glasby, 1999; Connell \& Glasby, 2001; Lindegarth, 2001; Zalmon \& Gomes, 2003).

Benthic organisms attached to artificial surfaces act both as structuring agents of the local environment and as a link in the marine trophic chain (Pinnegar et al., 2000; Relini et al., 2002). The structural complexity caused by dead or live "engineering species" transforms the environment through their own growth. Such organisms promote the formation of new habitats for other species, changing the initially flat surface into a complex and heterogeneous system, favoring the settling of new species (Fernandez et al., 2000; Ferreira et al., 2001; Cerda \& Castilla, 2001; Castilla \& Cerda, 2004). Biofouling also acts in energy transference from the reef complex to the associated fish, as available feeding items (Relini et al., 2002; Ferreira et al., 2004; Osman \& Whitlatch, 2004).

In the northern coast of Rio de Janeiro State, an artificial reef complex was implanted in 1996 aiming to study the development of the fouling community in different materials. Experimental structures of rubber, cement and concrete were tested as experimental surfaces for larvae settlement, the latter being the most stable and with a higher colonization rate (Zalmon \& Gomes, 2003).

The present study aimed to determine the functional role of biofouling to the fish community associated to artificial modules. We hypothesized that the composition, density, diversity and richness of the ichthyic community is related to the structural complexity of the substrate and to biofouling.

\section{Material And Methods}

The northern coast of Rio de Janeiro $\left(21^{\circ} 29 \mathrm{~S}, 41^{\circ} 00 \mathrm{~W}\right)$ lacks heterogeneous and natural consolidate substrate (Zalmon et al., 2002). Epibenthic organisms such as bryozoans, hydrozoans, colonial tunicates and barnacles are commonly found in detached algae stems (e.g. Dyctyopteris and Sargassun). Considering the absence of natural reefs, these factors favored experimental studies with artificial habitats in this region. The artificial reef complex was established 3 miles from Manguinhos beach, $9 \mathrm{~m}$ deep on a flat bottom.
The biofouling study was carried out in different stages between 1997 and 2004. Zalmon \& Gomes (2003) evaluated the effect of different materials on the fouling community structure, while Krohling et al. (2004) studied the effect of stressing factors (turbidity, abrasion, low chlorophyll concentration and the absence of natural substrates) on the recruitment and development of the local fouling community. In the present study, concrete experimental plates were used attached to the external surface of the artificial reefs to sample the fouling community. Half of the plates were painted with an anti-fouling paint (Tritao Cooperkote - Akzo Nobel Coatings) while the other half was left unpainted. Both sets of plates (painted and unpainted) were submerged in January/2003. Monthly, over 12 months, four plates from each set were retrieved and analyzed. Due to a heavy marine surge, it was not possible to remove the plates in the $7^{\text {th }}$ month of submersion. In the laboratory, the biofouling was identified and quantified by the intersection point technique (Sutherland, 1974). The fouling community was evaluated through its taxonomic composition, relative abundance, structural difference index (Goren, 1979) and turnover rate (Talbot et al., 1978). The two latter reflect quali-quantitative community changes, considering relative species abundance and immigration versus extinction rate on each sampling period.

Monthly, the fish community was sampled with gillnets of $25 \times 7 \mathrm{~m}, 30 \mathrm{~mm}$ mesh, for the stomach content analysis of all 240 caught individuals (Brotto et al., 2004) and through underwater visual censuses on summer months of 2003 and $2004(\mathrm{~N}=8$ sampling censuses), due to the low water visibility on the rest of the year.

A total of 36 reef modules were divided into four treatments, according to the degree of structural complexity (with or without shelter, due to the presence of cavities) and to the fouling community (with or without fouling, due to the use of anti-fouling paint): (1) WCWB - with complexity/with benthos; (2) WCNB - with complexity/no benthos; (3) NCWB - no complexity/with benthos; (4) NCNB - no complexity/no benthos (Fig. 1).

To check for significant differences in fish density, richness and diversity sampled by visual censuses in the different experimental modules we used analysis of variance (ANOVA) followed by $a$ posteriori Tukey's test (HSD) of the data $(\mathrm{p}<0.05)$ (Zar, 1984). The proportion of stomach content number / prey number were compared among module types using a Chi-square test $\left(X^{2}\right)$. The relation between ichthyic and fouling communities was tested through Pearson's correlation analysis of fish abundance (density) with fouling richness and diversity in the reefs with benthic cover (WB). 


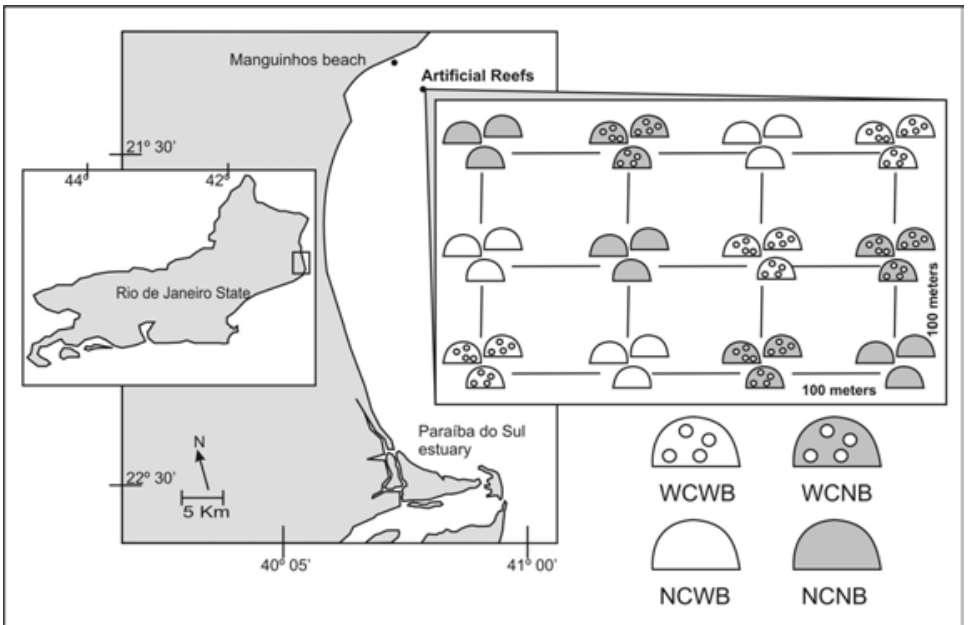

Fig. 1. North coast of Rio de Janeiro State, representation of the reef complex installed and details of the four types of experimental modules. (1) WCWB - with complexity/with benthos; (2) WCNB - with complexity/no benthos; (3) NCWB - no complexity/with benthos; (4) NCNB - no complexity/no benthos.

\section{RESULTS}

In previous studies (Zalmon \& Gomes, 2003; Brotto et al., 2004) as well as in the present one, the initial phases of colonization (1st to 3rd month) in the reef complex were characterized by an abundance of empty space and coverage of barnacles and hydrozoans higher than $20 \%$. Empty space showed a decreasing trend over time after submersion, concomitant to the occupation of the substrate by the fouling organisms (Fig. 2).

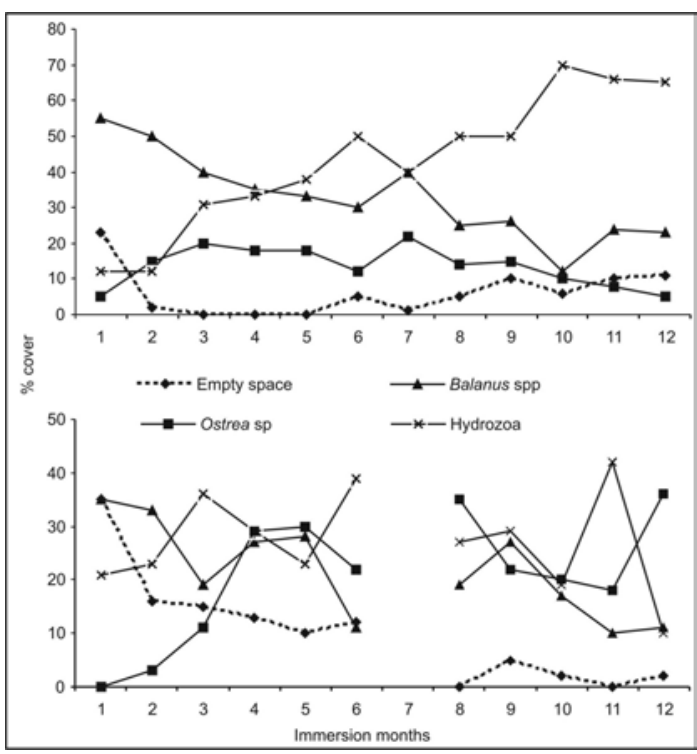

Fig. 2. Temporal variation of the covering percentage of the most abundant taxa present on experimental plates from March/1997 to February/1998 (above, Zalmon \& Gomes, 2003) and from February/2002 to January/2003 (below, present study). 
After the initial period, plates were colonized mainly by the hydroids Bougainvillia sp and Obelia sp and by the bivalve Ostrea sp. On the painted plates, the fouling occurred after the $8^{\text {th }}$ month of submersion, with open space greater than $70 \%$. Antifoul antifouling action of paint was extremely restricted as observed on the $6^{\text {th }}$ month. In this case, there was no epibiosis over the plates, but the fixation tag was fully recovered by Bougainvillia sp.

The structural difference index of the fouling community revealed higher values in the initial colonization stages $\left(1^{\text {st }}\right.$ to $3^{\text {rd }}$ months $)$, reater than $50 \%$, due to the replacement of the dominant organisms Obelia and Balanus spp by Bougainvillia sp and Ostrea sp and to the reduction in empty space from the $3^{\text {rd }}$ month on (Fig. 3a). The turnover rate showed the highest value in the first two months $(45 \%)$, reflecting the availability of the area to be colonized and the immigration of several species onto the new substrate (Fig. 3b). After the initial period, the turnover rate showed a decreasing trend. The lowest value occurred in the $11^{\text {th }}$ month $(7 \%)$, which indicates reduced changes in the species composition. The rise in the turnover rate during the last phase of observation (27\%) corresponded to the immigration of Chlorophyta sp2, Chlorophyta sp3, Holoporella sp, Obelia bidentata, Plumularia sp, Porifera $\mathrm{sp}$ and Tunicata sp1 and the extinction of Balanus venustus, Clytia linearis, Obelia dichotoma, Orthopyxis sp and Ostrea sp.

The stomach content of fish caught during the studied period (January/2003 to February/2004) revealed 18 feeding items, represented mainly by Crustacea and non-identified fish. The modules with benthic coverage showed a larger variety of items $(\mathrm{NCWB}=15, \mathrm{WCWB}=13, \mathrm{WCNB}=8, \mathrm{NCNB}=8)$, besides a higher abundance in the number of prey $(\mathrm{NCWB}=80, \mathrm{WCWB}=65, \mathrm{WCNB}=60, \mathrm{NCNB}=$ 48) (Table 1). The $X^{2}$ test showed a higher variety of prey at modules with benthic community (WCWB and NCWB) (Table 2).

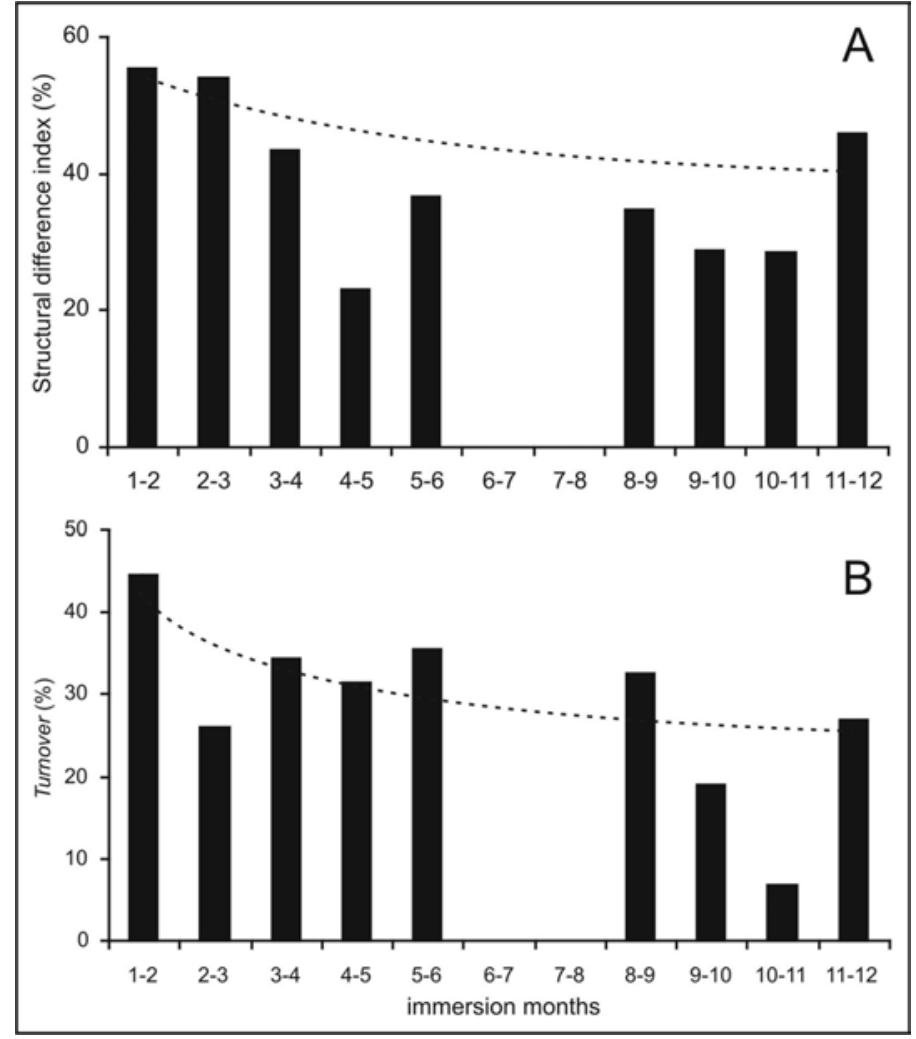

Fig. 3. Structural difference index (A), Turnover rate (B) and tendency line of the fouling community during the studies from 2002 to 2003. 
Table 1. Absolute $(\mathrm{AB})$ and relative abundance $(\%)$ of prey items found in fish stomach contents associated to different module types (WCWB - with complexity/with benthos; WCNB - with complexity/no benthos; NCWB - no complexity/with benthos; NCNB - no complexity/no benthos). * Mean values \pm standard deviation of number of preys.

\begin{tabular}{|c|c|c|c|c|c|c|c|c|}
\hline \multirow[t]{2}{*}{ PREY ITEMS } & \multicolumn{2}{|c|}{$\begin{array}{c}\text { WCWB } \\
\text { Stomach }(\mathrm{n}=71) \\
* 1.48 \pm 1.87\end{array}$} & \multicolumn{2}{|c|}{$\begin{array}{c}\text { WCNB } \\
\text { Stomach }(\mathrm{n}=37) \\
* 1.05 \pm 0.71\end{array}$} & \multicolumn{2}{|c|}{$\begin{array}{c}\text { NCWB } \\
\text { Stomach }(\mathrm{n}=66) \\
* 1.51 \pm 3.03\end{array}$} & \multicolumn{2}{|c|}{$\begin{array}{c}\mathrm{NCNB} \\
\text { Stomach }(\mathrm{n}=66) \\
* 1.22 \pm 1.49\end{array}$} \\
\hline & $\mathrm{AB}$ & $\%$ & $\mathrm{AB}$ & $\%$ & $\mathrm{AB}$ & $\%$ & $\mathrm{AB}$ & $\%$ \\
\hline Crustacea N/I & 20 & 30.8 & 15 & 31.3 & 26 & 32.5 & 18 & 30.0 \\
\hline Osteichthyes N/I & 19 & 29.2 & 21 & 43.8 & 25 & 31.3 & 30 & 50.0 \\
\hline Mollusca N/I & 6 & 9.2 & 0 & 0.0 & 0 & 0.0 & 0 & 0.0 \\
\hline Rodophyta calcareous & 4 & 6.2 & 1 & 2.1 & 1 & 1.3 & 1 & 1.7 \\
\hline Decapoda & 3 & 4.6 & 6 & 12.5 & 4 & 5.0 & 2 & 3.3 \\
\hline Ulva $\mathrm{sp}$ & 3 & 4.6 & 1 & 2.1 & 1 & 1.3 & 0 & 0.0 \\
\hline Lolliguncula brevis & 2 & 3.1 & 2 & 4.2 & 2 & 2.5 & 1 & 1.7 \\
\hline Isopoda & 2 & 3.1 & 1 & 2.1 & 2 & 2.5 & 0 & 0.0 \\
\hline Polychaeta & 2 & 3.1 & 0 & 0.0 & 6 & 7.5 & 4 & 6.7 \\
\hline Trichiurus lepturus & 1 & 1.5 & 0 & 0.0 & 1 & 1.3 & 0 & 0.0 \\
\hline Brachyura & 1 & 1.5 & 0 & 0.0 & 1 & 1.3 & 0 & 0.0 \\
\hline Brachiopoda & 1 & 1.5 & 0 & 0.0 & 0 & 0.0 & 0 & 0.0 \\
\hline Anthozoa & 1 & 1.5 & 0 & 0.0 & 0 & 0.0 & 0 & 0.0 \\
\hline Portunidae & 0 & 0.0 & 1 & 2.1 & 2 & 2.5 & 0 & 0.0 \\
\hline Loligo sp & 0 & 0.0 & 0 & 0.0 & 6 & 7.5 & 3 & 5.0 \\
\hline Symphurus plagusia & 0 & 0.0 & 0 & 0.0 & 1 & 1.3 & 0 & 0.0 \\
\hline Harengula sp & 0 & 0.0 & 0 & 0.0 & 1 & 1.3 & 1 & 1.7 \\
\hline Bryozoa & 0 & 0.0 & 0 & 0.0 & 1 & 1.3 & 0 & 0.0 \\
\hline TOTAL & 65 & 100 & 48 & 100 & 80 & 100 & 60 & 100 \\
\hline
\end{tabular}

Table 2. Chi-square test $\left(X^{2}\right)$ and corresponding significant level $(p)$ of the proportion of stomach contents number/ prey number between module types $(\mathrm{N}=36,3$ sampling units of each module type x 12 months, WCWB - with complexity/with benthos, WCNB - with complexity/no benthos, NCWB - no complexity/with benthos, NCNB no complexity/no benthos).

\begin{tabular}{cccc}
\hline \hline $\begin{array}{c}\text { Comparisons between } \\
\text { module types }\end{array}$ & $X^{2}$ & $p$ & RESULT \\
\hline WCWB X WCNB & 9.15 & $0.010 *$ & WCWB $>$ WCNB \\
WCWB X NCWB & 3.08 & $0.214 \mathrm{NS}$ & WCWB $=$ NCWB \\
WCWB X NCNB & 3.54 & $0.170 \mathrm{NS}$ & WCWB $=$ NCNB \\
WCNB X NCWB & 16.07 & $0.000 *$ & WCNB $<$ NCWB \\
WCNB X NCNB & 2.40 & $0.301 \mathrm{NS}$ & WCNB $=$ NCNB \\
NCWB X NCNB & 12.79 & $0.002 *$ & NCWB $>$ NCNB \\
\hline
\end{tabular}

$* \mathrm{p}<0.05 ; \mathrm{NS}-$ not significative. 
The visual census sampling program revealed a higher density, richness and species diversity at modules WCWB (with complexity/with benthos) and lower values at NCNB (no complexity/no benthos). Modules with higher structural complexity and with benthic organisms (WCWB and WCNB) presented significant higher values $(\mathrm{P}<0.05)$ of community structural indexes with the exception of species richness (Fig. 4).

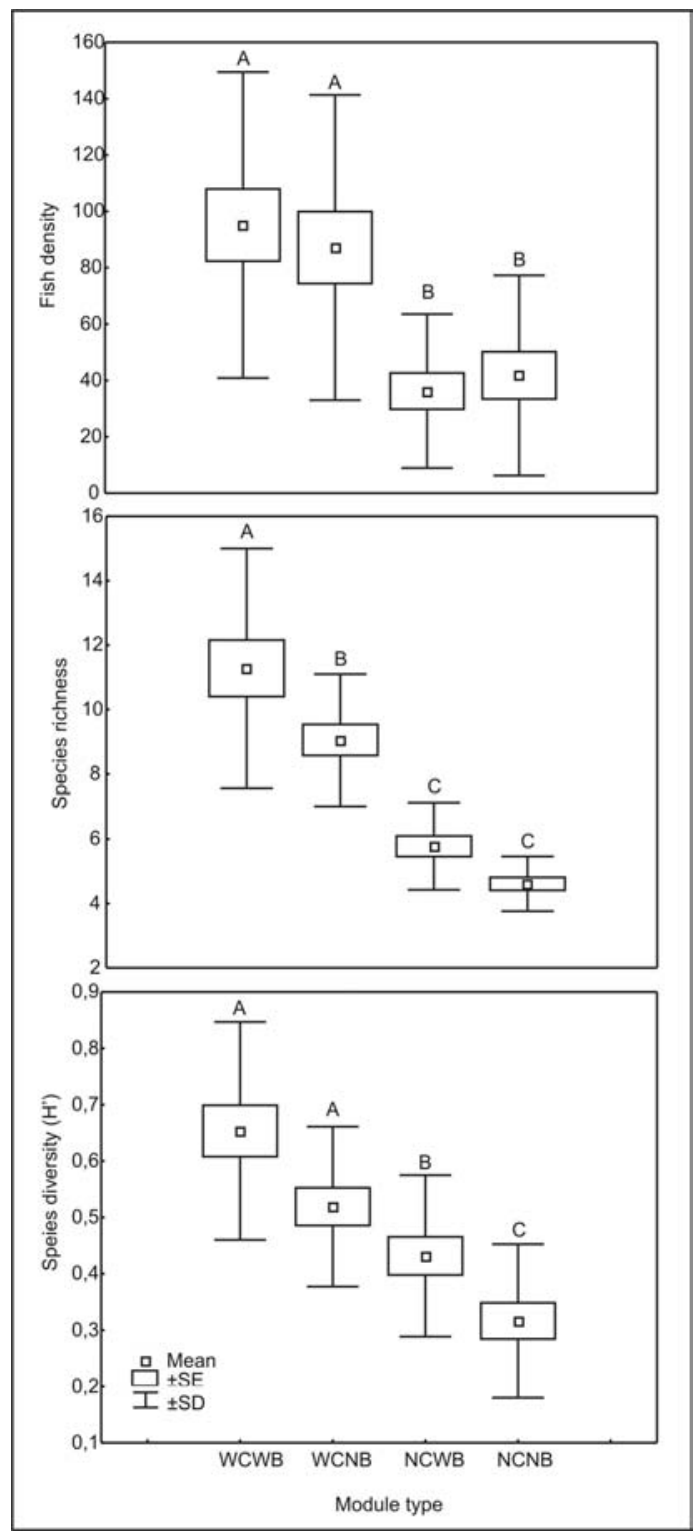

Fig. 4. Fish density, richness and Shannon's diversity through visual census (mean \pm standard error and standard deviation) in the four types of experimental modules in the summer 2003/2004; (1) WCWB - with complexity/with benthos; (2) WCNB - with complexity/no benthos; (3) NCWB - no complexity/with benthos; (4) NCNB - no complexity/no benthos (Tukey HSD, $\mathrm{p}<0.05$ ). 
Positive and significant correlations were found between fish density and fouling organisms diversity $(\mathrm{r}=0.58: \mathrm{P}<0.001)$ and richness $(\mathrm{r}=0.51: \mathrm{P}$ $=0.001)$ at modules with benthic organisms (WCWB and NCWB), although the high data dispersion (Fig. $5)$.

\section{Discussion}

Biofouling in artificial reefs might play different functional roles, e.g. as a link in the marine trophic chain (Pinnegar et al., 2000; Relini et al., 2002), reinforcing the idea of production in artificial reef environments (Carr \& Hixon, 1997; Sosa-Cordero et al., 1998) and as a facilitator in the recruitment of fish species, which benefit from the structural complexity as shelter in reef environments (Ferreira et al., 2001).

The relation between structural complexity versus ichthyic community is evident in several marine ecosystems. The microhabitats in coral reefs and salt-marsh roots in tropical estuaries are examples of sheltering place, food and breeding opportunity for several fish species (Carpenter et al., 1981; Chabanet et al. 1997; Jenkins \& Wheatley, 1998; Mumby et al., 2004). In the present study, the gradual increment of the structural complexity becomes evident when we analyze the structural difference index and the turnover rate, which showed higher values in the last phases of colonization (with the immigration of several taxa), increasing the offer of shelter and/or food for the ichthyic community. In the last months of colonization, the reefs were covered mainly by hydrozoans with up to $20 \mathrm{~cm}$ high (personal observation). Such organisms are responsible for the increasing of the superficial tridimensionality of the experimental modules, increasing the habitat complexity and thus, favoring the fish species which use the structures as shelters. These organisms that form new habitats ("engineering species") change the initially flat surface into a complex and threedimensional structure and transform the environment through their own growth (Fernandez et al., 2000; Cerda \& Castilla, 2001; Castilla \& Cerda, 2004).

The reef WCWB has lateral cavities and the fouling organisms colonize the internal and external surfaces. This characteristic enables the fouling to cover all the available area of these reefs offering additional shelter and food. The absence of this characteristic in the modules with complexity/no benthos reflected in the second type of reef with higher density, richness and diversity of fish. This structure was covered with anti-fouling paint on the external surface, but was left unpainted in the internal part, offering areas to be colonized by the fouling organisms even in the non-benthic modules. This fact emphasizes the work of Ferreira et al. (2001), in the region of Arraial do Cabo, RJ, who verified that sites with an abundance of sessile organisms promoted a higher structural complexity, resulting in a higher diversity and richness of reef fish species.

Bohnsack et al. (1991) suggest that two mechanisms act together in the colonization of an artificial reef: (i) the creation of new habitats with the reef structures submersion and (ii) the increase of benthic biomass. The latter can be explained by the role of the physical structure of the artificial reef as an accumulator and generator of propagules and organic sediments (Fang, 1992).

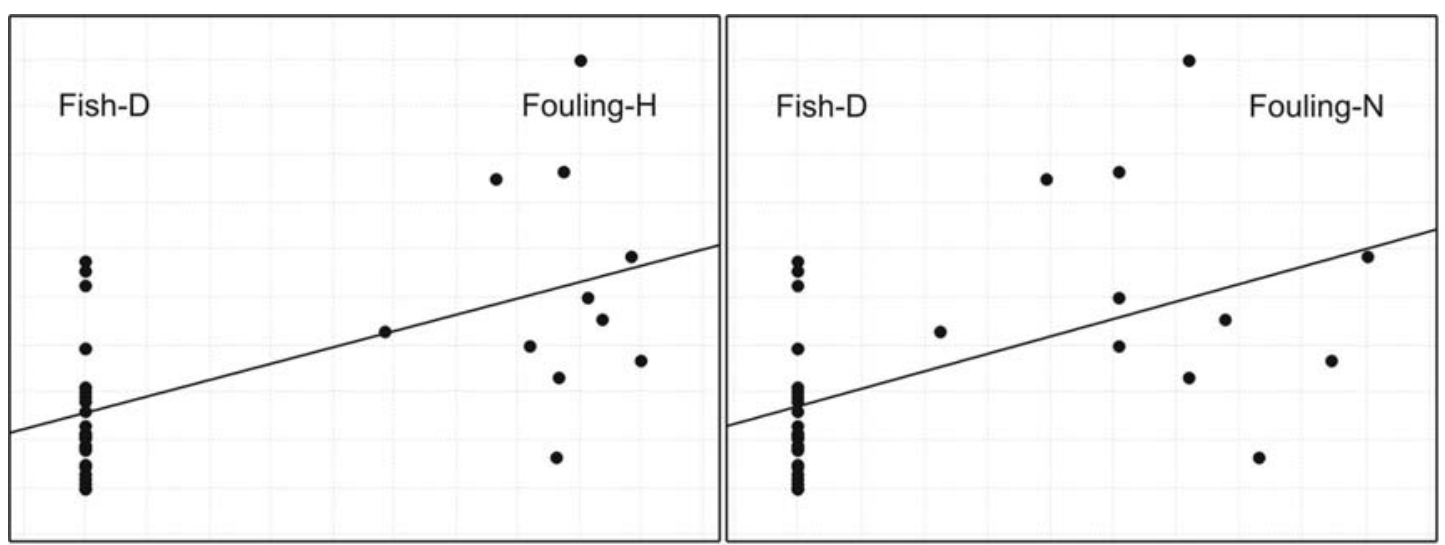

Fig. 5. Dispersion diagram of Pearson's correlation between fish density (Fish-D) with fouling diversity (Fouling-H: $r=0.58: \mathrm{P}$ $<0.001$ ) and fish density (Fish-D) with fouling richness (Fouling-N: $r=0.51: \mathrm{P}=0.001$ ) on modules with benthos (WCWB and NCWB). 
The fish stomach content analysis showed a higher variety of prey in the fish stomach associated to with benthic modules (WB). This module type presented a higher variety of prey in the stomach contents. Therefore, it is suggested that these fish obtained more diverse feeding resources when they explored the consolidate substrate of the reef modules as an additional food source. Such fact highlight the role of an artificial reef in the provision of feeding resources for the ichthyic community, where transference of energy occurs from the reef complex to the associated fish in the form of available feeding items.

Predation occurred in similar proportions in all four-module types. Larger species such as Rhyzoprionodon porosus (Caribean sharpnose shark), Menticirrhus americanus (Southern kingcroaker), Cynoscion virescens and C. jamaicensis (Green weakfish) were the most abundant fish caught by gillnets. Although these species are not commonly associated with consolidate substrates, it is admitted that these fish visit the reef complex, due to the potential attraction of the reefs to their preys (small fish and invertebrates).

The relationship between the ichthyic community and biofouling indicates that its functional role in the artificial reef complex is more shelter than feeding resources. The increase of the structural complexity offered by the reef itself and by the fouling organisms, which act as "engineering species" (i.e. barnacles, hydroids and bivalves) render more options of food and/or protection to the ichthyic community. Also, the epibiont biomass represents an important link in the trophic chain, acting as a direct source of food and/or energy transference to higher trophic levels. Such facts lead to the partial acceptance of the hypothesis that the composition, density and diversity of the ichthyic community are associated mainly with the structural complexity of the substrate and second to biofouling, which maximize the structural complexity of the system.

\section{ACKNOWLEDGEMENTS}

We would like to thank CNPq - National Counsel of Research and Development (Proc. $\mathrm{N}^{\mathrm{o}}$ 302303/2002-2, 470093/2003-0) and FAPERJ Research Foundation of Rio de Janeiro (Proc. N ${ }^{\circ}$ E26/171-046/96, E26/171-446/2000) for the financial support.

\section{REFERENCES}

Anderson, M. J. \& Underwood, A. J. 1994. Effects of substratum on the recruitment and development of an intertidal estuarine fouling assemblage. J. expl mar. Biol. Ecol., 184:217-236.

Bohnsack, J. A.; Johnson, D. L. \& Anderson, R. 1991. Ecology of artificial reefs habitats and fishes. In: W. Seaman, Jr, \& - Sprague, L.M., eds. Artificial habitats for marine and freshwater fisheries. California: Academic Press. p. 61-107.

Brotto, D. S.; Krohling, W. \& Zalmon, I. R. 2004. Usage patterns of an artificial reef by the fish community on the northern coast of Rio de Janeiro - Brazil. J. coast. Res., SI (39):1122-1125.

Carpenter, K.E.; Miclat, R. I.; Albaladejo, V. D. \& Corpuz, V. T. 1981. The influence of substrate structure on the local abundance and diversity of Philippine reef fishes. Proc. 4th Int. Coral Reef Symp. 2:497-502.

Carr, M. H. \& Hixon, M. A. 1997. Artificial reefs: the importance of comparisons with natural reefs. Fisheries, 22(4):28-33

Castilla, J. C. \& Cerda, M. 2004. Marine ecosystem engineering by the alien ascidian Pyura praeputialis on a mid-intertidal rocky shore. Mar. Ecol. Prog. Ser., 268:119-130.

Cerda, M. \& Castilla, J. C. 2001. Diversidad y biomasa de macro-invertebrados en matrices intermareales del tunicado Pyura praeputialis (Heller, 1878) en la Bahía de Antofagasta, Chile. Revta chil. Hist. Nat., 74, (4):841-853.

Chabanet, P.; Ralambondrainy, H.; Amanieu M.; Faure, G. \& Galzin, R. 1997. Relationships between coral reef substrata and fish. Coral Reefs, 16:93-102.

Connell, S. D. \& Glasby, T. M. 1999. Do urban structures influence local abundance and diversity of subtidal epibiota? A case study from Sydney Harbour, Australia. Mar. environ. Res., 47:373-387.

Connell, S. D. \& Glasby, T. M. 2001. Urban structures as marine habitats: an experimental comparison of the composition and abundance of subtidal epibiota among pilings, pontoons and rock reefs. Mar. environ. Res., 52:115-125.

Dowling, R. K. \& Nichol, J. 2001. The HMAS Swan artificial dive reef. An. Tour. Res., 28:226-229.

Fang, L. S. 1992. A theoretical approach of estimating the productivity of artificial ref. Acta zool. Taiwan, 3:5-10.

Fernandez, M.; Jaramillo, E.; Marquet, P. A.; Moreno, C. A.; Navarrete, S. A.; Ojeda, F. A.; Valdovinos, C.O.; Vasquez, J. A. 2000. Diversity, dynamics and biogeography of Chilean benthic nearshore ecosystems: an overview and guidelines for conservation. Revta chil... Hist. Nat., 73 (4):797-830.

Ferreira, C. E. L.; Gonçalves, J. E. A. \& Coutinho, R. 2001. Community structure of fishes and habitat complexity on a tropical rocky shore. Environ. Biol. Fishes, 61: 353369.

Ferreira, C.E.L.; Floeter, S.R.; Gasparini, J.L.; Joyeux, J.C. 2004. Trophic structure patterns of Brazilian reef fishes: a latitudinal comparison. J. Biogeogr., 31:1093-1106.

Goren, M. 1979. Succession of Benthic Community on Artificial Substratum at Elat (Red Sea). J. expl. mar. Biol. Ecol., 38:19-40.

Jenkins, G. P. \& Wheatley, M. J. 1998. The influence of habitat complexity on nearshore fish assemblages in a southern Australian embayment: comparison of shallow seagrass, reefalgal and unvegetated sand habitats, with 
Emphasis on their importance to recruitment. J. expl. mar. Biol. Ecol., 221:147-172.

Krohling, W.; Brotto, D. S. \& Zalmon, I. R. 2004. Fouling community recruitment on an artificial reef in the north coast of Rio de Janeiro State. J. coast.. Res., SI (39) no prelo. (ainda não foi publicado).

Lindegarth, M. 2001. Assemblages of animals around urban structures: testing hypotheses of patterns in sediment under boat-mooring pontoons. Mar. environ. Res. 51:289-300

Maher, T. F. 1999. Florida's artificial reef program: historical perspective of its unique partnership between Federal, State and local governments. Proceedings 7 th CARAH,:209-220.

Mumby, P. J.; Edwards, A. J.; Arias-Gonzalez, J. E.; Lindeman, K. C.; Blackwell, P. G.; Gall, A.; Gorczynska, M. I.; Harborne, A. R.; Pescod, C. L.; Renken, H.; Wabnitz, C. C. C. \& Llewellyn, G. 2004 Mangroves enhance the biomass of coral reef fish communities in the Caribbean. Nature, 427:533-536.

Osman, R. O. \& Whitlatch, R. B. 2004. The control of the development of a marine benthic community by predation on recruits. J. expl. mar.. Biol. Ecol., 311:117145.

Pearce, J. B. \& Chang, S. 1982. The efficacy of various materials in artificial reef construction. ICES J. mar. Sci., 64:1-11.

Pinnegar, J. K.; Polunin, N. V. C.; Francour, P.; Baladamenti, F.; Chemello, R.; Harmelin-Vivien, M. L.; Hereu, B.; Milazzo, M.; Zabala, M.; D’Anna, G. \& Pipitone, C. 2000. Trophic cascades in benthic marine ecosystems: lessons for fisheries and protected-area management. Environ. Conserv., 27 (2):179-200.

Relini, G. M.; Torchia, G. \& de Angelis, G. 2002. Trophic relationships between fishes and an artificial reef. ICES J. mar. Sci., 59:36-42.
Sosa-Cordero, E.; Arce, A. M.; Aguilar-Davila, W. \& Ramirez-Gonzalez, A. 1998. Artificial shelters for spiny lobster Panulirus argus (Latreille): an evaluation of occupancy in different benthic habitats. J. expl. mar. . Biol. Ecol., 229:1-18.

Sutherland, J. P. 1974. Multiple stable points in natural communities. Am. Nat., 108 (964):859-873.

Talbot, F. H.; Russel, B. C. \& Anderson, G. R. V. 1978. Coral reef fish communities: unstable high-diversity system? Ecol. Monogr., 48:425-440.

Tsumura, K.; Kakimoto, H. \& Noda, M. 1999. The history and future of artificial reefs and related aquatic habitats in Japan. Proceedings 7th CARAH, 1:264-271.

Underwood, A. J. \& Anderson, M. J. 1994. Seasonal and temporal aspects of recruitment and succession in as intertidal estuarine fouling assemblage. J. mar. biol. Ass.. U.K. , 74:563-584.

Zalmon, I. R.; Novelli, R.; Gomes, M. P. \& Farias, V. V. 2002. Experimental results of an artificial reef programme on the Brazilian coast north of Rio de Janeiro. ICES J. Mar. Sci., 59 (SI): 83-87.

Zalmon, I. R. \& Gomes, F. A. C. 2003. Comunidade incrustante em diferentes materiais de um recife artificial no litoral norte do Estado do Rio de Janeiro. Biotemas, 16(1):57-80.

Zar, J. H. 1984. Biostatistical Analysis. $2^{\text {nd }}$ ed. Englewood Cliffs, N.J., Prentice-Hall, 718p.

(Manuscript received 16 December 2005; revised 07 August 2006; accepted 12 September 2006) 